\title{
LOOK BACK WITH PRIDE: MEMORIES OF THE ENGLISH DEPARTMENT ${ }^{1}$
}

Ladies and gentlemen,

Ninety years is a respectable age for a university department. From my personal perspective this period can be divided into three unequal parts: in round numbers, thirty + forty + twenty years. The first segment covers the initial three decades in the life of the Department (1929-1961), before I joined it; the second and longest, my active service in it (1961-2000); and the third, "passive" service following my official retirement, with continued daily presence in my office and availability for unofficial consultations (2000 to the present). From this it follows that I have been associated with the Department in one form or another for nearly sixty years, or roughly the last two-thirds of its existence so far - a fact which fills me with pride.

We have already heard from the current Head, Dr Tomović, about the founding of the Department and its early history, of which I obviously have no direct experience. Picking up from there, in what follows I will take note of the long period of my association with it, in the form of recalling certain important events and figures as seen through my own eyes. In other words, this will be an informal address consisting of personal memories, just so as to warm you up for the intellectual and social feast awaiting you at this conference.

Let me start with a comment on the title of this initial section of the conference programme: "Reminiscences for the future - distinguished voices from the English Department". It is no doubt a clever heading: while it would be difficult to reminisce about the future, reminiscing for the future is a welcome exercise in that it establishes a much-needed temporal continuity by linking - in T.S.Eliot's famous words - time present with time past and time future. Speaking for myself now, mine is certainly a voice from the English Department, but it is just as certainly a voice from the past. As implied by my foregoing remarks, I can pose as a walking history of this institution (though walking isn't exactly my forte these days, as you may infer from the presence of my walking stick by my side). And with reference to our series of six international conferences to date, I note in passing that I have been privileged by participating in

\footnotetext{
“Faculty of Philology, University of Belgrade, Studentski trg 3, 11000 Belgrade, Serbia; e-mail: rbugarski@ fil.bg.ac.rs

${ }^{1}$ Extended version of the opening speech at the BELLS90 conference in Belgrade (30 May 2019). Due to a technical error, this text is printed in Volume 2 instead of Volume 1 of this publication.
} 
every one of them as a plenary speaker. This distinction led to my being proclaimed, at the previous event of this kind, the trademark of English Department conferences, a title I bear with pride and gratitude.

But enough of me - so let's turn to myself instead. I joined the Department on February 1, 1961, as an assistant lecturer in English language. (Besides my appointment here, I recall that the same year of grace was marked by two other major events, of lesser import by comparison but still worthy of note: awarding the Nobel prize for literature to a Yugoslav writer, Ivo Andrić, and the first world conference of non-aligned countries, held in Belgrade). I had applied for the newly opened position on the advice of Mrs Mary Stansfield Popović. So what did I find on my arrival here? Well, I found a staff of nearly thirty professors, lecturers, native and foreign lektors, as well as a fairly large and generally keen body of students.

Without wishing to belittle the indispensable role of the other staff members within the "reporting period", and not forgetting the valuable contributions of those who came later and hence remain outside my scope in these reflections, I will mention here only the names of the professors who held that rank or acquired it within a few years after my joining the Department. On the language side, these are Ljubomir Mihailović, Draginja Pervaz, Ljiljana Mihailović and Ksenija Anastasijević. In literature, Vida Marković (who had just succeeded Mrs Stansfied Popović as Head), Borivoje Nedić, Ivanka Kovačević, Olga Humo, Dušan Puhalo, Ranka Kuić, Veselin Kostić, Nićifor Naumov and Vidosava Janković. To these I will add three assistant lecturers who were apppointed at the same as I: Ivo Ćurčin and Ileana Čura for literature, and Naum Dimitrijević for English teaching methodology. I note with sadness that all these distinguished scholars and fine people have in the meantime passed away; it is therefore even more fitting for their names, which remain forever inscribed in the annals of the English Department, to be mentioned on this occasion.

Thanks to them and their associates we had adequate modern curricula, with both teaching and research maintaining a high level. These activities were supported by the British Council, the British and United States Embassies and the Fulbright Commission. This support included courses and lectures by a long line of leading British and American scholars and writers of the time, such as Randolph Quirk, A.C. Gimson, Pit Corder, Henry Widdowson, Frank Palmer, Stephen Ullmann, Eric Hamp, Archibald Hill, Ronald Langacker, John Robert Ross, David Daiches, Allardyce Nicoll, Saul Bellow, Lawrence Durrell, Angus Wilson, Alan Sillitoe - to name but a few.

In the opposite direction, Department members were able to obtain grants for study and research in Great Britain and the United States at least once in several years. I myself did very well in this respect. I spent the academic year 1962/63 as a postgraduate supervised by Prof. Randolph Quirk at University College London, on a grant from the British Fund for Yugoslav Scholars. In 1966/67 I was a Ford Foundation- 
sponsored visiting scholar at Columbia University in New York. Finally, in 1969/70 I was a Fulbright lecturer at several American universities, based at the University of Chicago, and a visiting professor of linguistics at Northeastern Illinois State College, also in Chicago (which was upgraded to Northeastern Illinois University soon after my departure, no doubt as a result of my having taught there). I owe much of whatever I may have achieved in my academic life to these three periods within less than a decade.

Another important contribution was made over the years by English language officers, serving as liaison between the British Council and English-teaching institutions in the country. Among these I single out Alan Maley, who later became a well-known lecturer and author in the area of FLT, specifically ELT, EFL and TEFL, former president of IATEFL, whom I met again only last month on the occasion of an ELTA conference here in Belgrade, when Branka Panić, a leading TEFL person in Serbia, hosted a delightful social evening in his honour. You will hardly be surprised to hear that we barely recognised each other after an interval of, as it turned out, over half a century!

Incidentally, you may have noticed how the general field of teaching English as a foreign language, known as TEFL, swarms with acronyms and other abbreviations: FLT, ELT, ELTA, EFL, TEFL, IATEFL... (I nearly added TEFLON, but remembered in the nick of time that this item would have been misplaced, the odd man out so to speak, belonging as it does to the register of industrial chemistry rather than to this particular set!).

But back to myself again, I was well received by staff and students alike, instantly came to love my job, and performed my various duties with enthusiasm. My engagement was accompanied by some amusing incidents, of which I vividly remember one in particular. Namely, in my first year here the story went round the Faculty of Philology that its English Department was quite unusal, in fact unique in the world, in offering a course in - Bulgarian idioms! Now what was behind this? Well, the answer is not far to seek. Among my assignments was a course in English idioms, listed among other subjects in the timetable posted on the wall, containing information on the lecturer's surname and, beneath it, the name of the course. So my slot said

\section{BUGARSKI}

\section{IDIOMI}

which, if read in succession, could be interpreted as "Bulgarian idioms", as my surname is homographic with the Serbian adjective meaning 'Bulgarian' (in pronunciation, however, there is an accentual difference). 
And so on over the decades of sharing the Department's ups and downs as an eager witness of its ongoing history. Not counting my first twenty years at our previous location in Takovska street, I have worked in my present office in these premises for the following forty years, even after my official retirement - which makes my room easily the most used single-occupant office in the building. And this introduces my final joke, which I call the inventory stocktaking story. Every once in a while our rooms are visited by designated technical staff to make sure that all the pieces of furniture are in place, by checking the kind and number of items against their lists. So the story is abroad that in the case of my office the recital goes as follows: "bookshelf -2 , desk -1 , easy chair -3 , small table -1 , Professor Bugarski - 1" (it sounds even better in Serbian, ending with "profesor Bugarski - komada 1").

Friends and colleagues, with these words the hero of the preceding anecdote, also known as Mr Trademark, thanks you for bearing with him and wishes you a good conference and a pleasant stay in Belgrade! 